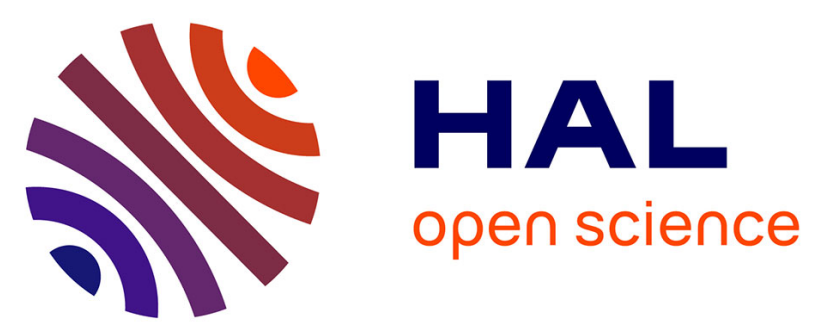

\title{
Low Rate of Virological Failure and Maintenance of Susceptibility to HIV-1 Protease Inhibitors with First-Line Lopinavir/Ritonavir-Based Antiretroviral Treatment in Clinical Practice
}

Mattia Cf Prosperi, Maurizio Zazzi, Grazia Punzi, Laura Monno, Grazia Colao, Paola Corsi, Simona Di Giambenedetto, Genny Meini, Valeria Ghisetti, Stefano Bonora, et al.

\section{- To cite this version:}

Mattia Cf Prosperi, Maurizio Zazzi, Grazia Punzi, Laura Monno, Grazia Colao, et al.. Low Rate of Virological Failure and Maintenance of Susceptibility to HIV-1 Protease Inhibitors with First-Line Lopinavir/Ritonavir-Based Antiretroviral Treatment in Clinical Practice. Journal of Medical Virology, 2010, 82 (12), pp.1996. 10.1002/jmv.21927 . hal-00589435

\section{HAL Id: hal-00589435 https://hal.science/hal-00589435}

Submitted on 29 Apr 2011

HAL is a multi-disciplinary open access archive for the deposit and dissemination of scientific research documents, whether they are published or not. The documents may come from teaching and research institutions in France or abroad, or from public or private research centers.
L'archive ouverte pluridisciplinaire HAL, est destinée au dépôt et à la diffusion de documents scientifiques de niveau recherche, publiés ou non, émanant des établissements d'enseignement et de recherche français ou étrangers, des laboratoires publics ou privés. 


\section{Journal of Medical Virology}

WILEY

\section{Low Rate of Virological Failure and Maintenance of Susceptibility to HIV-1 Protease Inhibitors with First-Line Lopinavir/Ritonavir-Based Antiretroviral Treatment in Clinical Practice}

\begin{tabular}{|c|c|}
\hline Journal: & Journal of Medical Virology \\
\hline Manuscript ID: & JMV-10-1726.R2 \\
\hline Wiley - Manuscript type: & Research Article \\
\hline $\begin{array}{r}\text { Date Submitted by the } \\
\text { Author: }\end{array}$ & 08-Jul-2010 \\
\hline Complete List of Authors: & $\begin{array}{l}\text { Prosperi, Mattia; Catholic University of Sacred Heart, Clinic of } \\
\text { Infectious Diseases } \\
\text { Zazzi, Maurizio; University of Siena, Molecular Biology } \\
\text { Punzi, Grazia; Bari University Hospital, Microbiology and Virology } \\
\text { Monno, Laura; Bari University Hospital, Clinical Infectious Diseases } \\
\text { Colao, Grazia; Careggi University Hospital, Microbiology and } \\
\text { Virology } \\
\text { Corsi, Paola; Careggi University Hospital, Unit of Infectious } \\
\text { Diseases } \\
\text { Di Giambenedetto, Simona; Catholic Universisty of Sacred Heart, } \\
\text { Clinic of Infectious Diseases } \\
\text { Meini, Genny; University of Siena, Molecular Biology } \\
\text { Ghisetti, Valeria; A. Savoia Hospital, Microbiology and Virology } \\
\text { bonora, stefano; university of Torino, infectiuos diseases } \\
\text { Pecorari, Monica; Modena University Hospital, Microbiology and } \\
\text { Virology } \\
\text { Gismondo, Maria Rita; L. Sacco University Hospital, Microbiology } \\
\text { and Virology } \\
\text { Bagnarelli, Patrizia; Ancona University Hospital, Microbiology and } \\
\text { Virology } \\
\text { Carli, Tiziana; Grosseto General Hospital, Unit of Infectious } \\
\text { Diseases } \\
\text { De Luca, Andrea; Sacro Cuore Catholic University, Institute of } \\
\text { Infectious Diseases; University Hospital of Siena, Infectious } \\
\text { Diseases Unit }\end{array}$ \\
\hline Keywords: & $\begin{array}{l}\text { human immunodeficiency virus type } 1 \text {, lopinavir/ritonavir, first-line } \\
\text { antiretroviral therapy, genotypic resistance, virologic failure }\end{array}$ \\
\hline
\end{tabular}




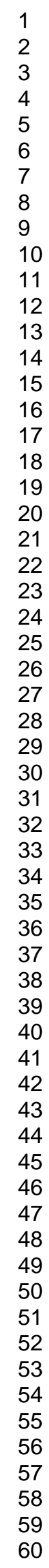

\section{SCHOLARONE" \\ Manuscripts}

14

15

16

18

19

20

22

23

25

26

27

29

32

33

34

35

36

39

40

41

43

44

45

46

47

48

50

51

52

54

55

58

59

60

John Wiley \& Sons 
Table 1a. Multivariable Cox regression analysis: predictors of virological failure beginning from month 6 after treatment initiation $(n=548)$. HIV-RNA measured at or after 6 months

\begin{tabular}{|c|c|c|c|c|c|c|c|c|}
\hline \multirow{2}{*}{\multicolumn{3}{|c|}{ factor }} & \multicolumn{3}{|c|}{$>50$ copies $/ \mathrm{ml}$} & \multicolumn{3}{|c|}{$>500$ copies $/ \mathrm{ml}$} \\
\hline & & & $\mathrm{RH}$ & $95 \% \mathrm{Cl}$ & p-value & $\mathrm{RH}$ & $95 \% \mathrm{Cl}$ & $\mathrm{p}$-value \\
\hline \multicolumn{3}{|c|}{ year of birth (per 1-year increase) } & 0.994 & $(0.958-1.03)$ & 0.725 & 1.024 & $(0.983-1.066)$ & 0.264 \\
\hline \multirow{2}{*}{\multicolumn{2}{|c|}{ gender }} & male vs. female & 0.649 & $(0.298-1.415)$ & 0.277 & 0.575 & $(0.248-1.336)$ & 0.198 \\
\hline & & unknown vs. female & 1.041 & $(0.128-8.463)$ & 0.970 & 1.374 & $(0.17-11.079)$ & 0.765 \\
\hline \multirow{3}{*}{\multicolumn{2}{|c|}{ mode of HIV transmission }} & homo/bisexual vs. heterosexual & 1.264 & $(0.524-3.046)$ & 0.602 & 1.368 & $(0.53-3.534)$ & 0.517 \\
\hline & & intravenous drug user vs. heterosexual & 0.512 & $(0.105-2.498)$ & 0.408 & 1.519 & $(0.432-5.346)$ & 0.515 \\
\hline & & other/unknown vs. heterosexual & 1.236 & $(0.558-2.737)$ & 0.602 & 1.156 & $(0.477-2.802)$ & 0.748 \\
\hline \multicolumn{3}{|c|}{ calendar year of HAART initiation (per more recent) } & 0.919 & $(0.719-1.174)$ & 0.497 & 0.978 & $(0.733-1.304)$ & 0.878 \\
\hline \multirow{4}{*}{$\begin{array}{l}\text { backbone } \\
\text { HAART }\end{array}$} & \multicolumn{2}{|c|}{ abacavir+lamivudine vs. tenofovir+emtricitabine } & 0.362 & $(0.079-1.65)$ & 0.189 & 0.197 & $(0.025-1.533)$ & 0.121 \\
\hline & \multicolumn{2}{|c|}{ zidovudine+lamivudine vs. tenofovir+emtricitabine } & 1.142 & $(0.47-2.773)$ & 0.769 & 0.991 & $(0.375-2.619)$ & 0.986 \\
\hline & \multicolumn{2}{|c|}{ other backbone vs. tenofovir+emtricitabine } & 1.592 & $(0.403-6.299)$ & 0.507 & 1.936 & $(0.402-9.323)$ & 0.410 \\
\hline & \multicolumn{2}{|c|}{ tenofovir+lamivudine vs. tenofovir+emtricitabine } & 0.275 & $(0.056-1.361)$ & 0.114 & 0.754 & $(0.206-2.767)$ & 0.671 \\
\hline \multicolumn{3}{|c|}{ baseline CD4+ cell count cells/mm3 (per log higher) } & 0.844 & $(0.656-1.087)$ & 0.190 & 0.892 & $(0.679-1.173)$ & 0.414 \\
\hline \multicolumn{3}{|c|}{ baseline HIV-RNA load cp/ml (per log10 higher) } & 0.844 & $(0.529-1.348)$ & 0.479 & 1.790 & $(1.097-2.921)$ & 0.020 \\
\hline \multicolumn{3}{|c|}{ lopinavir GRS (per 10 points higher) } & 0.975 & $(0.912-1.042)$ & 0.450 & 0.945 & $(0.89-1.003)$ & 0.064 \\
\hline \multicolumn{3}{|c|}{ backbone GRS (per 10 points higher) } & 1.002 & $(0.979-1.026)$ & 0.849 & 1.038 & $(1.017-1.06)$ & 0.0003 \\
\hline
\end{tabular}

Table 1b. Multivariable Cox regression analysis: predictors of virological failure beginning from month 3 after treatment initiation $(n=548)$. HIV-RNA measured at or after 3 months

\begin{tabular}{|c|c|c|c|c|c|c|c|c|}
\hline \multirow{2}{*}{\multicolumn{3}{|c|}{ Factor }} & \multicolumn{3}{|c|}{$>50$ copies $/ \mathrm{ml}$} & \multicolumn{3}{|c|}{$>500$ copies $/ \mathrm{ml}$} \\
\hline & & & $\mathrm{RH}$ & $95 \% \mathrm{Cl}$ & p-value & $\mathrm{RH}$ & $95 \% \mathrm{Cl}$ & p-value \\
\hline \multicolumn{3}{|c|}{ year of birth (per 1 year increase) } & 1.018 & $(0.991-1.045)$ & 0.2012 & 1.032 & $(1.002-1.063)$ & 0.0365 \\
\hline \multirow{2}{*}{\multicolumn{2}{|c|}{ gender }} & male vs. female & 1.233 & $(0.679-2.239)$ & 0.4915 & 0.918 & $(0.504-1.67)$ & 0.7784 \\
\hline & & unknown vs. female & 1.497 & $(0.339-6.605)$ & 0.5941 & 0.468 & $(0.06-3.63)$ & 0.4677 \\
\hline \multirow{3}{*}{\multicolumn{2}{|c|}{ mode of HIV transmission }} & homo/bisexual vs. heterosexual & 0.875 & $(0.468-1.634)$ & 0.6751 & 0.827 & $(0.407-1.678)$ & 0.5984 \\
\hline & & intravenous drug user vs. heterosexual & 0.202 & $(0.046-0.892)$ & 0.0348 & 1.065 & $(0.433-2.621)$ & 0.8909 \\
\hline & & other/unknown vs. heterosexual & 0.935 & $(0.517-1.69)$ & 0.8228 & 1.223 & $(0.673-2.225)$ & 0.5091 \\
\hline \multicolumn{3}{|c|}{ calendar year of HAART initiation (per more recent) } & 0.974 & $(0.805-1.178)$ & 0.7859 & 1.101 & $(0.903-1.343)$ & 0.3402 \\
\hline \multirow{4}{*}{$\begin{array}{l}\text { backbone } \\
\text { HAART }\end{array}$} & \multicolumn{2}{|c|}{ abacavir+lamivudine vs. tenofovir+emtricitabine } & 0.255 & $(0.077-0.849)$ & 0.0259 & 0.111 & $(0.015-0.824)$ & 0.0316 \\
\hline & \multicolumn{2}{|c|}{ zidovudine+lamivudine vs. tenofovir+emtricitabine } & 0.895 & $(0.467-1.716)$ & 0.7386 & 1.138 & $(0.585-2.212)$ & 0.7041 \\
\hline & \multicolumn{2}{|c|}{ other backbone vs. tenofovir+emtricitabine } & 1.546 & $(0.505-4.737)$ & 0.4457 & 2.015 & $(0.646-6.291)$ & 0.2275 \\
\hline & \multicolumn{2}{|c|}{ tenofovir+lamivudine vs. tenofovir+emtricitabine } & 0.897 & $(0.397-2.029)$ & 0.7948 & 1.199 & $(0.485-2.967)$ & 0.6938 \\
\hline \multicolumn{3}{|c|}{ baseline CD4+ cell count cells/mm3 (per log higher) } & 0.875 & $(0.732-1.047)$ & 0.145 & 0.967 & $(0.795-1.176)$ & 0.7382 \\
\hline \multicolumn{3}{|c|}{ baseline HIV-RNA load cp/ml (per log10 higher) } & 1.127 & $(0.799-1.589)$ & 0.4968 & 1.901 & $(1.312-2.754)$ & 0.0007 \\
\hline \multicolumn{3}{|c|}{ lopinavir GRS (per 10 points higher) } & 0.997 & $(0.958-1.039)$ & 0.9007 & 0.999 & $(0.966-1.032)$ & 0.9361 \\
\hline \multicolumn{3}{|c|}{ backbone GRS (per 10 points higher) } & 1.001 & $(0.983-1.02)$ & 0.8793 & 1.021 & $(1.005-1.037)$ & 0.0101 \\
\hline
\end{tabular}

$\mathrm{RH}=$ relative hazard; HAART = highly active antiretroviral therapy; GRS = Stanford's 6.0.1 genotypic resistance score 
Table 2. Evolution of protease and reverse transcriptase resistance mutations under lopinavir/ritonavir plus 2 nucleoside/tide reverse transcriptase inhibitors pressure in 36 previously naive patients with available baseline and follow-up HIV-1 genotype. Substitutions emerging during treatment are in bold.

\begin{tabular}{|c|c|c|c|c|c|}
\hline patient & nrtia & $\begin{array}{l}\text { Baseline } \\
\text { HIV-RNA } \\
\text { load } \\
\text { Log10 } \\
\text { copies/ml }\end{array}$ & Baseline genotype & Follow-up genotypeb & $\begin{array}{l}\text { LPV/rtv } \\
\text { susceptbility } \\
\text { (baseline/follow-up)c }\end{array}$ \\
\hline 1 & 3TC TDF & 6.76 & $\begin{array}{l}\text { PR: } 63 P \\
\text { RT: }\end{array}$ & $\begin{array}{l}\text { PR: 63P } \\
\text { RT: } 41 \mathrm{~L} 70 R \text { 101Q 103N 181C 210W 215F 215Y 219E 221Y 225H 238T }\end{array}$ & $S / S$ \\
\hline 2 & FTC TDF & 5.72 & $\begin{array}{l}\text { PR: } 63 P \\
\text { RT: }\end{array}$ & $\begin{array}{l}\text { PR: } 63 P \\
\text { RT: } 1841\end{array}$ & $S / S$ \\
\hline 3 & 3TC TDF & 5.18 & $\begin{array}{l}\text { PR: 10F 20T 46I 54V 63P 71T 73T 84V 90M } \\
\text { RT: 41L 70R 74V 103N 118I 184V 215F 219Q 228H }\end{array}$ & $\begin{array}{l}\text { PR: 10F 20T 46I 54V 63P 71T 73T 84V 90M } \\
\text { RT: 41L 70R 74V 103N 118I 184V 215F 219Q 228H }\end{array}$ & $1 / /$ \\
\hline 4 & FTC TDF & 5.53 & $\begin{array}{l}\text { PR: } 16 \mathrm{E} 20 \mathrm{R} 36 \mathrm{l} \\
\text { RT: }\end{array}$ & $\begin{array}{l}\text { PR: } 16 \text { E 20R 36l } \\
\text { RT: }\end{array}$ & $S / S$ \\
\hline 5 & 3TC AZT & 5.12 & $\begin{array}{l}\text { PR: } 36160 E \\
\text { RT: } 101 Q\end{array}$ & $\begin{array}{l}\text { PR: } 36 \mathrm{l} 60 \mathrm{E} \\
\text { RT: } 101 \mathrm{1} 184 \mathrm{~V}\end{array}$ & $S / S$ \\
\hline 6 & FTC TDF & 5.70 & 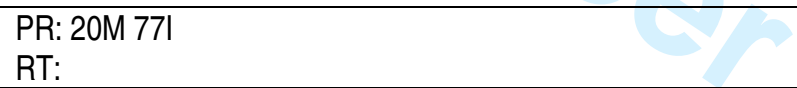 & $\begin{array}{l}\text { PR: } 771 \\
\text { RT: }\end{array}$ & $S / S$ \\
\hline 7 & FTC TDF & 4.93 & $\begin{array}{l}\text { PR: 13V 63P 77I } \\
\text { RT: }\end{array}$ & $\begin{array}{l}\text { PR: 13V 63P 77l } \\
\text { RT: }\end{array}$ & $S / S$ \\
\hline 8 & FTC TDF & 5.86 & $\begin{array}{l}\text { PR: 10I 11I 20V 32I 33F 36I 43T 63P 71V 73S 82A 89V 90M } \\
\text { RT: 215D }\end{array}$ & $\begin{array}{l}\text { PR: 10I } 20 \mathrm{~V} 32 \mathrm{I} 33 \mathrm{~F} 36 \mathrm{I} 43 \mathrm{~T} \text { 46I 47V 54V 63P 71V 73S 82A 89V 90M } \\
\text { RT: 44D 118I 184V 215Y }\end{array}$ & $\mathrm{R} / \mathrm{R}$ \\
\hline 9 & FTC TDF & 6.25 & $\begin{array}{l}\text { PR: } 36163 P \\
\text { RT: }\end{array}$ & $\begin{array}{l}\text { PR: } 63 P \\
\text { RT: }\end{array}$ & $S / S$ \\
\hline 10 & ЗTC AZT & 5.17 & $\begin{array}{l}\text { PR: 63P 71T } \\
\text { RT: }\end{array}$ & $\begin{array}{l}\text { PR: 63P 71T } \\
\text { RT: }\end{array}$ & $S / S$ \\
\hline 11 & FTC TDF & 5.70 & $\begin{array}{l}\text { PR: 10V 13V 16E 20M 35G 36L } \\
\text { RT: }\end{array}$ & $\begin{array}{l}\text { PR: 10V 13V 16E 20M 35G 36L } \\
\text { RT: }\end{array}$ & $S / S$ \\
\hline 12 & FTC TDF & 4.77 & $\begin{array}{l}\text { PR: } 821 \\
\text { RT: }\end{array}$ & $\begin{array}{l}\text { PR: } 361821 \\
\text { RT: }\end{array}$ & $S / S$ \\
\hline 13 & FTC TDF & 5.70 & $\begin{array}{l}\text { PR: } 63 P \text { 77I } \\
\text { RT: 333D }\end{array}$ & $\begin{array}{l}\text { PR: 63P 77l } \\
\text { RT: 333D }\end{array}$ & $S / S$ \\
\hline 14 & ЗТC AZT & 4.17 & $\begin{array}{l}\text { PR: } 36193 \mathrm{~L} \\
\text { RT: }\end{array}$ & $\begin{array}{l}\text { PR: 36I 63P 93L } \\
\text { RT: }\end{array}$ & $S / S$ \\
\hline 15 & 3TC AZT & 4.18 & $\begin{array}{l}\text { PR: } 10 \mathrm{I} 13 \mathrm{~V} 36 \mathrm{I} 58 \mathrm{E} 60 \mathrm{E} \\
\text { RT: } 103 \mathrm{~N} 184 \mathrm{I} 184 \mathrm{~V}\end{array}$ & $\begin{array}{l}\text { PR: } 10 \mathrm{I} 13 \mathrm{~V} 36 \mathrm{I} 58 \mathrm{E} 60 \mathrm{E} \\
\text { RT: } 103 \mathrm{~N} 184 \mathrm{~V}\end{array}$ & $S / S$ \\
\hline 16 & D4T DDI & 5.17 & $\begin{array}{l}\text { PR: 10l 46I 60E 63P 73T 77I 84V 90M 93L } \\
\text { RT: 41L 67N 101E 181C 190A 215Y 219Q 228H }\end{array}$ & $\begin{array}{l}\text { PR: 10F 20I 36I 46I 54V 60E 63P 73T 84V 90M 93L } \\
\text { RT: 41L 67N 101E 108I 118I 181C 190A 210W 215Y 219R 221Y }\end{array}$ & $1 / 1$ \\
\hline
\end{tabular}




\begin{tabular}{|c|c|c|c|c|c|}
\hline 17 & 3TC D4T & 4.56 & $\begin{array}{l}\text { PR: 10F 33I 35G 36I 46I 63P 71V 73S 83D 84V 90M } \\
\text { RT: 41L 44D 67N 74I 74V 103N 118I 181C 210W 215Y 219R }\end{array}$ & $\begin{array}{l}\text { PR: 10F 20V 36I 46I 54V 63P 71V 73S 84V 90M } \\
\text { RT: 41L 44D 67N 74V 101Q 118I 184V 210W 215Y 219R }\end{array}$ & $1 / /$ \\
\hline 18 & ЗТC AZT & 5.31 & $\begin{array}{l}\text { PR: } 13 \mathrm{~V} \text { 16A 58E 60E 77l } \\
\text { RT: } 179 \mathrm{D}\end{array}$ & $\begin{array}{l}\text { PR: 13V 16A 58E 60E 77I } \\
\text { RT: 179D }\end{array}$ & $S / S$ \\
\hline 19 & 3TC AZT & 5.26 & $\begin{array}{l}\text { PR: 60E 63P 71T 77I } \\
\text { RT: } 106 \mathrm{I} 138 \mathrm{G} 1791\end{array}$ & $\begin{array}{l}\text { PR: 60E 63P 71T 77l } \\
\text { RT: } 1061 \text { 138G }\end{array}$ & $S / S$ \\
\hline 20 & D4T TDF & 5.17 & $\begin{array}{l}\text { PR: 10F 35D 36I 54V 63P 711 84V 93L } \\
\text { RT: 41L 67G 74V 101P 184V 210W 215Y }\end{array}$ & $\begin{array}{l}\text { PR: 10F 35D 361 46I 54V 63P 711 84V 93L } \\
\text { RT: 41L 67G 74V 101P 210W 215Y }\end{array}$ & $1 / /$ \\
\hline 21 & 3TC AZT & 5.69 & $\begin{array}{l}\text { PR: } 71 T \text { 771 } \\
\text { RT: }\end{array}$ & $\begin{array}{l}\text { PR: 35D 71T 77I } \\
\text { RT: }\end{array}$ & $S / S$ \\
\hline 22 & D4T TDF & 5.46 & $\begin{array}{l}\text { PR: 10F 63P 771 } \\
\text { RT: }\end{array}$ & $\begin{array}{l}\text { PR: } 63 P \\
\text { RT: }\end{array}$ & $S / S$ \\
\hline 23 & 3TC AZT & 5.17 & $\begin{array}{l}\text { PR: 63P 77I 93L } \\
\text { RT: }\end{array}$ & $\begin{array}{l}\text { PR: 63P 77I 93L } \\
\text { RT: }\end{array}$ & $S / S$ \\
\hline 24 & 3TC TDF & 5.03 & $\begin{array}{l}\text { PR: 36I 63P } \\
\text { RT: } 103 R\end{array}$ & $\begin{array}{l}\text { PR: 36I 63P } \\
\text { RT: } 103 R\end{array}$ & $S / S$ \\
\hline 25 & 3TC TDF & 5.70 & $\begin{array}{l}\text { PR: } 201361 \\
\text { RT: }\end{array}$ & $\begin{array}{l}\text { PR: 10F 13V 20I 20M 36I 63P 77I 82I } \\
\text { RT: 184V 215C 215S 215Y }\end{array}$ & $S / S$ \\
\hline 26 & 3TC AZT & 5.00 & $\begin{array}{l}\text { PR: } 13 \mathrm{~V} \\
\text { RT: }\end{array}$ & $\begin{array}{l}\text { PR: } 13 \mathrm{~V} \\
\text { RT: }\end{array}$ & $S / S$ \\
\hline 27 & ЗТC TDF & 5.56 & $\begin{array}{l}\text { PR: 10V 20V 36I 47V 54V 63P 71V 73S 82A 89V 90M } \\
\text { RT: 215F 215S }\end{array}$ & $\begin{array}{l}\text { PR: 10V 20V 36l 47V 54V 63P 71V 73S 82A 89V 90M } \\
\text { RT: 215F 215S 215Y }\end{array}$ & $\mathrm{R} / \mathrm{R}$ \\
\hline 28 & 3TC AZT & 4.59 & $\begin{array}{l}\text { PR: 20R 35D 36l } \\
\text { RT: }\end{array}$ & $\begin{array}{l}\text { PR: 20R 35D 36l } \\
\text { RT: }\end{array}$ & $S / S$ \\
\hline 29 & 3TC ABC & 5.85 & $\begin{array}{l}\text { PR: } 13 V 20135 \mathrm{~N} 36 \mathrm{~L} 60 \mathrm{E} 63 \mathrm{P} \\
\text { RT: }\end{array}$ & $\begin{array}{l}\text { PR: } 10113 V 20136 \mathrm{~L} 60 \mathrm{E} 63 \mathrm{P} \\
\text { RT: }\end{array}$ & $S / S$ \\
\hline 30 & FTC TDF & 5.31 & $\begin{array}{l}\text { PR: 63P } \\
\text { RT: }\end{array}$ & $\begin{array}{l}\text { PR: 63P } \\
\text { RT: }\end{array}$ & $S / S$ \\
\hline 31 & ЗТC AZT & 4.20 & $\begin{array}{l}\text { PR: } \\
\text { RT: } 67 N 219 Q\end{array}$ & $\begin{array}{l}\text { PR: } \\
\text { RT: 67N 219Q }\end{array}$ & $S / S$ \\
\hline 32 & FTC TDF & 5.44 & $\begin{array}{l}\text { PR: 63P 93L } \\
\text { RT: }\end{array}$ & $\begin{array}{l}\text { PR: 63P 93L } \\
\text { RT: }\end{array}$ & $S / S$ \\
\hline 33 & FTC TDF & 7.00 & $\begin{array}{l}\text { PR: } 10 \mathrm{~V} 13 \mathrm{~V} \\
\text { RT: }\end{array}$ & $\begin{array}{l}\text { PR: } 10 \mathrm{~V} 13 \mathrm{~V} \\
\text { RT: }\end{array}$ & $S / S$ \\
\hline 34 & FTC TDF & 5.81 & $\begin{array}{l}\text { PR: 60E 63P } \\
\text { RT: }\end{array}$ & $\begin{array}{l}\text { PR: 60E 63P } \\
\text { RT: }\end{array}$ & $S / S$ \\
\hline 35 & FTC TDF & 5.17 & $\begin{array}{l}\text { PR: 63P 71V 93L } \\
\text { RT: 69A 179l }\end{array}$ & $\begin{array}{l}\text { PR: 71V 93L } \\
\text { RT: }\end{array}$ & $S / S$ \\
\hline 36 & FTC TDF & 4.91 & $\begin{array}{l}\text { PR: } 10146 \mathrm{~L} 93 \mathrm{~L} \\
\text { RT: } 1181333 \mathrm{E}\end{array}$ & $\begin{array}{l}\text { PR: } 101 \text { 46L 93L } \\
\text { RT: } 1181\end{array}$ & $S / S$ \\
\hline
\end{tabular}


a3TC, lamivudine; ABC, abacavir; AZT, zidovudine; D4T, stavudine; DDI, didanosine; FTC, emtricitabine; TDF, tenofovir. bPR, protease; RT, reverse transcriptase.

cS, susceptible (Stanford's score <=14); I, intermediate resistance (Stanford's score from 15 to 59); R, high-level resistance (Stanford's score >=60). 
Figure 1. Kaplan-Meier curves of survival rates with respect to a virological failure at or after 3 or 6 months using different HIV-RNA thresholds (>1000, $>500$ and $>50 \mathrm{cp} / \mathrm{ml}$ ), to a Stanford's lopinavir genotypic resistance score $>14$ (intermediate/full resistance), to an accumulation of at least one major IAS resistance mutation to lopinavir/ritonavir, and to a therapy discontinuation (at any time for any reason) end-point. 
Figure 1. Kaplan-Meier curves of survival rates with respect to a virological failure at or after 3 or 6 months using different HIV-RNA thresholds $(>1000,>500$ and $>50 \mathrm{cp} / \mathrm{ml})$, to a Stanford's lopinavir genotypic resistance score $>14$ (intermediate/full resistance), to an accumulation of at least one major IAS resistance mutation to lopinavir/ritonavir, and to a therapy discontinuation (at any time for any reason) end-point. $370 \times 244 \mathrm{~mm}(96 \times 96 \mathrm{DPI})$ 
1 Low Rate of Virological Failure and Maintenance of Susceptibility to HIV-

21 Protease Inhibitors with First-Line Lopinavir/Ritonavir-Based

3 Antiretroviral Treatment in Clinical Practice

4

Mattia CF Prosperi ${ }^{1}$, Maurizio Zazzi ${ }^{2}$, Grazia Punzi ${ }^{3}$, Laura Monno ${ }^{4}$, Grazia Colao ${ }^{5}$, Paola Corsi ${ }^{6}$, Simona Di Giambenedetto $^{1}$, Genny Meini ${ }^{2}$, Valeria Ghisetti ${ }^{7}$, Stefano Bonora ${ }^{8}$, Monica Pecorari ${ }^{9}$, Maria Rita Gismondo $^{10}$, Patrizia Bagnarelli ${ }^{11}$, Tiziana Carli ${ }^{12}$, and Andrea De Luca ${ }^{1,13}$, for the ARCA Collaborative Group.

${ }^{1}$ Clinic of Infectious Diseases, Catholic University of Sacred Heart, Rome, Italy

${ }^{2}$ Department of Molecular Biology, University of Siena, Siena, Italy

${ }^{3}$ Microbiology and Virology, Bari University Hospital, Bari, Italy

${ }^{4}$ Clinical Infectious Diseases, Bari University Hospital, Bari, Italy

${ }^{5}$ Microbiology and Virology, Careggi University Hospital, Florence, Italy

${ }^{6}$ Unit of Infectious Diseases, Careggi University Hospital, Florence, Italy

${ }^{7}$ Microbiology and Virology, A. Savoia Hospital, Turin, Italy

${ }^{8}$ Unit of Infectious Diseases, A. Savoia Hospital, Turin, Italy

${ }^{9}$ Microbiology and Virology, Modena University Hospital, Modena, Italy

${ }^{10}$ Microbiology and Virology, L. Sacco University Hospital, Milan, Italy

${ }^{11}$ Microbiology and Virology, Ancona University Hospital, Ancona, Italy

${ }^{12}$ Unit of Infectious Diseases, Grosseto General Hospital, Grosseto, Italy

${ }^{13}$ Infectious Diseases Unit, Siena University Hospital, Siena, Italy

Correspondence to:

Mattia Prosperi, PhD

Clinic of Infectious Diseases

Catholic University of Sacred Heart

Largo F. Vito, 1 - 00168 - Rome, Italy

E-mail: ahnven@yahoo.it

Running head: First-line lopinavir/ritonavir HAART 


\section{Abstract}

Protease inhibitor (PI)-resistant HIV-1 has hardly ever been detected at failed boosted PI-based first-line antiretroviral regimens in clinical trials. However, this phenomenon has not been investigated in clinical practice. To address this gap, data from patients starting a first-line lopinavir/ritonavir (LPV/rtv)-based therapy with available baseline HIV-1 RNA load, a viral genotype and follow-up viral load after 3 months and 6 months of treatment were extracted from the Italian Antiretroviral Resistance Cohort Analysis (ARCA) observational database. Based on survival analysis, $39(7.1 \%)$ and $43(7.8 \%)$ of the 548 examined patient cases had an HIV-1 RNA $>500$ and $>50$ copies $/ \mathrm{ml}$, respectively, after 6 months of treatment. Cox proportional hazard models detected baseline HIV-1 RNA (RH 1.79, 95\% Cl 1.10-2.92 per 1- $\log _{10}$ increase, $\mathrm{P}=0.02$ ) and resistance to the nucleoside backbone $(\mathrm{RH} 1.04,95 \% \mathrm{Cl} 1.02-1.06$ per 10-point increase using the

\section{Key Words}

human immunodeficiency virus type 1; boosted protease inhibitor; lopinavir/ritonavir; first-line antiretroviral therapy; antiretroviral drug resistance; virologic failure. 
58 Word count: Abstract 249; Text 2,097. 


\section{Introduction}

60

Ritonavir-boosted protease inhibitors (PIs) have been used successfully for years and still remain a key component of highly active antiretroviral therapy (HAART). A major advantage of boosted PIs in first-line therapy is the very low risk of selecting drug-resistant HIV-1 variants at virological failure, as shown in multiple clinical trials [Bartlett et al., 2006; Gupta et al., 2008; Lima et al., 2008; Molina et al., 2008; Ortiz et al., 2008; Mills et al., 2009]. This feature is, in fact, the main argument made by experts favouring boosted PI over non-nucleoside reverse transcriptase inhibitor (NNRTI)-based first-line therapy because NNRTIs select typically for NNRTI-resistant virus at failure [Riddler et al., 2008]. In addition, resistance to the backbone nucleoside reverse transcriptase inhibitors (NRTIs) occurs less frequently with a boosted PI compared to an NNRTIbased therapy [Soulié et al., 2009].

While the latest treatment guidelines recommend other boosted PIs for first-line HAART [DHHS, 2009], lopinavir/ritonavir (LPV/rtv) has been the most widely used PI owing to its longstanding availability, unique heat-stable co-formulation, efficacy and safety profiles [Oldfield et al., genotype entry is dated back to 1991 . At the time of this study, data from 19,984 patients were 2006]. In order to evaluate virological response to first-line LPV/rtv-based therapy and confirm its low propensity for selecting resistance mutations in HIV-1 protease in clinical practice, a targeted analysis was carried out using the Italian Antiretroviral Resistance Cohort Analysis (ARCA) observational database. ARCA (www.hivarca.net) is a nationwide initiative started in 2002 which retrospectively and prospectively collates clinical and virological data from HIV-1-infected patients followed at 105 centres. The data include demographics, hepatitis B and C status, AIDS-defining events, antiretroviral treatment, viral load, CD4+ T cell counts, HIV-1 genotype. The oldest HIV-1 available. 


\section{Patients and Methods}

First-line treatments comprised of LPV/rtv plus two NRTIs were extracted from the ARCA database. All patients with available HIV-1 genotype and HIV-1 RNA load at baseline were included and all HIV-1 RNA load data available from the treatment start date to the latest follow-up time were collected. The rate of treatment failure and development of drug resistance were evaluated by survival analyses using the cases with at least one follow-up HIV-1 RNA load measurement obtained after 3 months and after 6 months of uninterrupted treatment. Information on HIV-1 genotype obtained between 30 days after treatment start and 90 days after LPV/rtv discontinuation was also included, if no other PI was administered after LPV/rtv.

The Stanford HIVdb version 6.0.1 (http://hivdb.stanford.edu/) algorithm was used to calculate genotypic resistance scores (GRS). HIVdb scores below 10 are classified as full drug susceptibility, from 10 to 14 as potential low-level resistance, from 15 to 29 as low-level resistance, from 30 to 59 as intermediate resistance and >59 as high-level resistance. This fivelevel system was converted to a three-category classification by grouping scores up to 14 as susceptibility, 15 to 59 as intermediate resistance and $>59$ as complete resistance. A continuous numeric GRS scale was used in the multivariable analysis in order to minimise the number of parameters to be optimised: results are showed per 10 points higher, which roughly corresponds to a one-category increase in the Stanford HIVdb categorisation.

Survival analysis using the Kaplan-Meier method and Cox proportional hazard models was performed using the following outcome measures: having an HIV-1 RNA load $>500$ and $>50$ copies/ml at 3 months after treatment initiation; an HIV-1 RNA load $>500$ and $>50$ copies $/ \mathrm{ml}$ at 6 months after treatment initiation; intermediate or full LPV/rtv resistance defined as a GRS >14; and the presence of at least one major LPV/rtv resistance mutation according to the 2009 IAS-USA list (i.e. V32I, 147A/V or $\mathrm{V} 82 \mathrm{~A} / \mathrm{F} / \mathrm{S} / \mathrm{T}$ ) [Johnson et al., 2009]. Cases not reaching the specific 
110 endpoint were censored at the regimen discontinuation date or at the latest available HIV-1 RNA

111 or HIV-1 genotype if the regimen was not discontinued. After adjusting for the other explanatory

112 variables, the Cox model provides an estimate of the treatment effect on the remaining data with 1013 no outcome event. In addition, the model allows estimating the outcome event hazard for each 11 12114 individual, based on his/her baseline variables. 


\section{Results}

The ARCA database contained 1,141 patients who were treated with first line LPV/rtvcontaining HAART regimens. Of these, 549 (48\%) did not have a baseline genotype and were excluded from the analysis. The remaining 592 patients had baseline median (IQR) CD4+ T cell counts and HIV-1 RNA load of 127 (48-255) cells $/ \mathrm{mm}^{3}$ and 5.20 (4.80-5.60) $\log _{10}$ copies/ml, respectively. The median (IQR) calendar year of LPV/rtv initiation was 2006 (2004-2007). The NRTI backbones employed most frequently were tenofovir plus emtricitabine (37.5\%), zidovudine plus lamivudine (34.3\%), abacavir plus lamivudine (12.2\%), and tenofovir plus lamivudine (10.6\%).

At baseline, $15(2.5 \%)$ and $1(0.2 \%)$ patients presented with a LPV/rtv intermediate and resistant GRS, respectively. The prevalence of genotypes carrying at least one major IAS mutation associated to LPV/rtv resistance was $7.3 \%(n=43)$. Intermediate and full resistance to at least one NRTI were detected in $5.4 \%$ and $2.5 \%$ of the cases, with $1.8 \%$ showing intermediate and $5.7 \%$ full resistance to at least one NNRTI; and $1.8 \%$ and $2.0 \%$ to at least one $\mathrm{PI}$, respectively. When looking at the GRS of the treatment provided, the prevalence of regimens with all fully active drugs (i.e. no drug with a GRS $>14$ ) was $93 \%$, while $2.9 \%$ of regimen were composed by either at least one drug with full resistance or two drugs with intermediate resistance. Ten (1.7\%) genotypes were found with both intermediate-level resistance to LPV/rtv and to at least one of the other drugs in the backbone.

Forty-four (7.4\%) of the 592 patients had not have a follow-up HIV-1 RNA measurement after 3 or 6 months hence were excluded from subsequent incidence and survival analyses. Following 3- and 6 months therapy, 74 (13.5\%) and 39 (7.1\%) patients had an HIV-1 RNA >500 copies/ml, respectively. Using the more stringent criterion, the number of cases with a confirmed HIV-1 RNA >50 copies/ml after 3 and 6 months were 77 (14\%) and 43 (7.8\%), respectively. 
According to Kaplan-Meier analysis (Fig. 1) the estimated proportion of patients with an

HIV-1 RNA below 500 copies/ml was $0.90(95 \% \mathrm{Cl} 0.86-0.94)$ at one year and $0.80(0.74-0.87)$ at

two years, with an incidence rate of $0.23(0.17-0.32)$ per 1,000 person-years of follow-up. With the 50-copy threshold, the probability to remain virological failure-free was $0.90(0.85-0.93)$ at one year and $0.73(0.65-0.81)$ at two years, with an incidence rate of $0.26(0.19-0.35)$ per 1,000 personyears of follow-up. The incidence rate of therapy discontinuation for any reason was 1.8 (1.7-2.1) per 1,000 person-years of follow-up. The probability of continuing the first-line LPV/rtv-based regimen was $0.51(0.46-0.56)$ at one year and $0.28(0.24-0.34)$ at two years. Notably, $26 \%$ of the $324 \mathrm{LPV} / \mathrm{rtv}$ therapy discontinuations at any follow-up time were owing to toxicity, $17 \%$ to treatment simplification, $3 \%$ to adherence problems, whereas $33 \%$ were on other grounds and $21 \%$ were stopped owing to unspecified reasons.

Multivariable Cox analysis showed that at 6 months a higher baseline HIV-1 RNA load and a higher NRTI backbone GRS were independent predictors of having viremia at $>500$ copies/ml, but not at $>50$ copies $/ \mathrm{ml}$ (Table $1 \mathrm{a}$ ). Factors predictive of virological failure at 3 months using the 500 copy and/or the 50-copy threshold were higher baseline viral load, older patient age, use of tenofovir/emtricitabine vs. abacavir/lamivudine and heterosexual vs. intravenous route of infection (Table 1b). However, drug users had less frequent visits, thus viral load monitoring, compared to other transmission groups (not shown). This may explain the apparently lower risk of short-term failure for drug users.

Follow-up of HIV-1 genotype was available for a total of 36 patients. Mutations associated with decreasing susceptibility to NRTIs, NNRTIs and PIs were detected at baseline in seven, five and six patients, respectively, with three patients harboring triple-class resistant virus. Overall, genotyping was carried out after a median of 220 days (IQR 102-348) from LPV/rtv initiation. Median HIV-1 RNA and CD4+ T cell count at the time of follow-up genotype were 3.64 (IQR 2.564.67) $\log _{10}$ copies/ml and $207(120-432)$ cells $/ \mathrm{mm}^{3}$. Eight $(22.2 \%)$ viral genotype tests were 
1

performed after LPV/rtv discontinuation. Paired analysis of the baseline and follow-up genotypes revealed very limited selection of protease mutations (Table 2). There were no changes in Stanford HIVdb LPV/rtv susceptibility category in any case. Among the 30 patients with a LPV/rtv-sensitive baseline genotype, only one was found with more than one additional minor PI mutation (patient 25: L10F, I13V, L63P, V77I, V82I) but this did not have any impact on the predicted LPV/rtv susceptibility. In some other cases, the baseline and follow-up genotype differed for one minor mutation, either acquired or lost. Resistance mutation $154 \mathrm{~V}$, contributing to resistance to LPV/rtv, was observed in three cases with pre-existing LPV/rtv resistance. In one of the four cases harboring a virus populations with intermediate resistance to LPV/rtv at baseline (patient 20), the major PI mutation M46I was identified at the follow-up stage. Moreover, major LPV/rtv mutations M46I and 147V were found in one of the two patients (patient 8) with a virus that was already highly resistant to LPV/rtv at baseline. There were four cases with NRTI resistance mutations, namely $\mathrm{M} 184 \mathrm{I} / \mathrm{V}$ with or without a more extensive set of NRTI resistance mutations. In one of these patients, the follow-up HIV-1 genotype also contained NNRTI resistance mutations as a result of NNRTI therapy following discontinuation of LPV/rtv. Overall, 30 of the 36 (83.3\%) followup genotypes were susceptible to LPV/rtv and to at least another PI, 33 (91.7\%) were susceptible to NNRTIs and to at least two NRTIs. 


\section{Discussion}

The use of boosted PIs as first-line HAART has been shown to be a valuable treatment option in clinical trials with virological failure being comparable or slightly higher than with NNRTIbased therapy [Riddler et al., 2008; Soriano et al., 2009; Daar et al., 2010]. However the residual number of effective drugs at failure has been generally far higher with boosted PIs [Bartlett et al., 2006; Gupta et al., 2008; Lima et al., 2008]. Although the underlying mechanism is not completely understood, it has been acknowledged that not only boosted PI failures devoid any major protease mutations but also resistance to the NRTI backbone is typically minimized by an apparently increased genetic barrier to resistance. Notwithstanding the excellent performance in clinical trials, evaluation of virological response and development of drug resistance with first-line boosted PI treatment in the different context of clinical practice is advisable. Larger heterogeneity and lower adherence rate of the patient population may introduce variables affecting the success of a treatment regimen based mostly on a high genetic barrier. Moreover, genotypic resistance assays in clinical trials are performed typically at the first sign of virological failure, while they may be delayed in clinical practice owing to practical constraints.

The analysis of a large multicentric observational cohort confirms both a very low rate of virologic failure, which is in some cases driven by pre-existing resistance, and a negligible selection of drug resistance in patients undergoing a LPV/rtv-based first-line regimen. The results shown with respect to the 6-month follow-up, which is more relevant in the current clinical settings, and for the 3-month end-point, which could be of interest in the evaluation of the predictors of early failure. Although the number of follow-up genotypes was limited, clinical trials of drug-naive patients have generated comparably low numbers of genotypic information at failure [Gupta et al., 2008]. In addition, patients with transmitted PI-resistant virus are generally excluded from boosted PI-based first-line treatment trials while such patients are encountered in clinical practice 
[Geretti, 2007] and may benefit from boosted PI therapy. Interestingly, it was observed that decreased susceptibility to the NRTI backbone appeared to compromise treatment more than decreased susceptibility to LPV/rtv. This highlights the potency of this high-genetic barrier PI, although the low number of cases with resistance at baseline may have hampered the detection of minor effects.

According to the genotypic susceptibility profile at failure, for the vast majority of patients a fully active regimen can be still based on a boosted PI or consisting of two NRTI plus one NNRTI. While novel drug classes are being considered for convenient and potentially less toxic first-line treatment, boosted PIs, particularly LPV/rtv, maintain an excellent and hardly achievable efficacy record of in terms of suppression of virus replication and limitation of drug resistance evolution. In addition, recent trial data suggest better tolerability and/or higher potency for the currently recommended boosted PIs compared to LPV/rtv [Madruga et al., 2007; Molina et al., 2008]. While this strengthens the importance of the PI class as a cornerstone in HAART, future analysis of large cohort data will be required to confirm such advantages in clinical practice. 
Acknowledgements

This work was supported, in part, by an unrestricted educational grant from Abbott Virology to ARCA. The sponsor played no role in study design, data analysis and manuscript revision. ARCA is supported by educational grants by Abbott, Boehringer-Ingelheim, Bristol-Myers Squibb, GlaxoSmithKline, Gilead Sciences, Janssen-Cilag Tibotec division. The study was supported partly by the European Community's Seventh Framework Programme (FP7/2007-2013) under the project "Collaborative HIV and Anti-HIV Drug Resistance Network (CHAIN)" - grant agreement number 223131. We are very grateful to Andrea Petroczi (Kingston University, UK) for critical reading of the manuscript.

\section{The ARCA collaborative group}

Andrea Giacometti (ANCONA - Clinica di Malattie Infettive), Luca Butini (ANCONA - Immunologia Clinica), Romana del Gobbo (ANCONA - Malattie Infettive), Stefano Menzo (ANCONA - Virologia), Danilo Tacconi (AREZZO - Malattie Infettive), Giovanni Corbelli (ASCOLI PICENO - Malattie Infettive), Stefania Zanussi (AVIANO - Centro di Riferimento Oncologico), Laura Monno (BARI - Clinica Malattie Infettive Università), Grazia Punzi (BARI - Virologia), Franco Maggiolo (BERGAMO - Malattie Infettive), Annapaola Callegaro (BERGAMO - Microbiologia e Virologia), Leonardo Calza (BOLOGNA - Malattie Infettive S. Orsola), Maria Carla Re (BOLOGNA - UO Microbiologia, Lab. Retrovirus), Raffaele Pristerà (BOLZANO - Malattie Infettive), Paola Turconi (BRESCIA - Fleming Labs), Antonella Mandas (CAGLIARI - Centro S.I.D.A., Policlinico Universitario), Sauro Tini (CITTA' DI CASTELLO - Medicina Generale), Alessia Zoncada (CREMONA - Malattie Infettive), Elisabetta Paolini (CREMONA - Servizio Immunoematologia e Medcina Trasfusionale), Giorgio Amadio (FERMO - Malattie Infettive), Laura Sighinolfi (FERRARA - Malattie Infettive AOU S. Anna), Giuliano Zuccati (FIRENZE - Centro MTS), Massimo Morfini (FIRENZE - Ematologia CAREGGI), Roberto Manetti (FIRENZE Immunoallergologia CAREGGI), Paola Corsi (FIRENZE - Malattie Infettive CAREGGI), Luisa Galli (FIRENZE - Malattie Infettive Pediatria Meyer), Massimo Di Pietro (FIRENZE - Malattie Infettive SM Annunziata), Filippo Bartalesi (FIRENZE Malattie Infettive Università), Grazia Colao (FIRENZE - Virologia CAREGGI), Andrea Tosti (FOLIGNO - Malattie Infettive / SERT), Antonio Di Biagio (GENOVA - Clinica Malattie Infettive AOU S. Martino), Maurizio Setti (GENOVA - Clinica Medica Immunologia), Bianca Bruzzone (GENOVA - Laboratorio di Igiene Ospedale S. Martino), Giovanni Penco (GENOVA - Malattie Infettive Ospedali Galliera), Michele Trezzi (GROSSETO - Malattie Infettive), Anna Orani (LECCO Malattie Infettive), Riccardo Pardelli (LIVORNO - Malattie Infettive), Michele De Gennaro (LUCCA - Malattie Infettive), Alessandro Chiodera (MACERATA - Malattie Infettive), Alfredo Scalzini (MANTOVA - Malattie Infettive Ospedale 'C. Poma'), Loredana Palvarini (MANTOVA - Virologia), Paolo Almi (MASSA - Malattie Infettive), Giovanni Todaro (MESSINA - Malattie Infettive), Antonella d'Arminio Monforte (MILANO - Clinica Malattie INfettive AO S. Paolo), Paola Cicconi (MILANO - Clinica di Malattie Infettive Ospedale S. Paolo), Stefano Rusconi (MILANO - Dipart. Scienze Cliniche, Sez. Malattie Infettive - Università degli Studi), Maria Rita Gismondo (MILANO - Laboratorio Microbiologia Ospedale L. Sacco (Dipart. Scienze Cliniche, Sez. Malattie Infettive)), Maria Rita Gismondo (MILANO - Laboratorio Microbiologia Ospedale L. Sacco (Prima Divisione Malattie Infettive)), Valeria Micheli (MILANO - Laboratorio Microbiologia Ospedale L. Sacco (Seconda Divisione Malattie Infettive)), Maria Luisa Biondi (MILANO - Laboratorio di diagnostica molecolare infettivologica AO S. Paolo), Nicola Gianotti (MILANO - Malattie Infettive San Raffaele), Amedeo Capetti (MILANO Prima Divisione Malattie Infettive Ospedale L. Sacco), Paola Meraviglia (MILANO - Seconda Divisione Malattie Infettive Ospedale L. Sacco), Enzo Boeri (MILANO - Virologia HSR), Cristina Mussini (MODENA - Clinica Malattie Infettive), Monica Pecorari (MODENA - Virologia), Alessandro Soria (MONZA - Malattie Infettive), Laura Vecchi (MONZA - UO Microbiologia AO S. Gerardo), Maurizio Santirocchi (NARNI - SERT), Diego Brustia (NOVARA - Malattie Infettive AO Maggiore), Paolo Ravanini (NOVARA - Virologia), Federico Dal Bello (PADOVA - Virologia), Nino Romano (PALERMO Centro Riferimento AIDS Università), Salvatrice Mancuso (PALERMO - Servizio Riferimento Regionale Diagnosi AIDS), Carlo Calzetti (PARMA - Divisione Malattie Infettive ed Epatologia Azienda Ospedaliera), Renato Maserati (PAVIA Ambulatorio Clinica Malattie Infettive S. Matteo), Gaetano Filice (PAVIA - Clinica Malattie Infettive e Tropicali), Fausto Baldanti (PAVIA - Virologia S. Matteo), Daniela Francisci (PERUGIA - Malattie Infettive), Giustino Parruti (PESCARA Malattie Infettive), Ennio Polilli (PESCARA - Virologia Pescara), Daria Sacchini (PIACENZA - Malattie Infettive), Chiara Martinelli (PISA - Malattie Infettive), Rita Consolini (PISA - Pediatria I Università), Linda Vatteroni (PISA - Virologia), Angela Vivarelli (PISTOIA - Malattie Infettive), Daniele Dionisio (PISTOIA - Virologia), Alessandro Nerli (PRATO Malattie Infettive), Lucia Lenzi (PRATO - Virologia), Giacomo Magnani (REGGIO EMILIA - Malattie Infettive), Patrizia Ortolani (RIMINI - Malattie Infettive RIMINI), Massimo Andreoni (ROMA - Cattedra Malattie Infettive Tor Vergata), Guido Palamara (ROMA - IRCCS S. Gallicano), Caterina Fimiani (ROMA - Immunologia Clinica Umberto I), Lucia Palmisano (ROMA - Istituto Superiore di Sanità), Andrea De Luca (ROMA - Istituto di Clinica Malattie Infettive Cattolica), Simona Di Giambenedetto (ROMA - Laboratorio virologia Cattolica), Vincenzo Vullo (ROMA - Malattie 
Infettive e Tropicali La Sapienza - Umberto I), Ombretta Turriziani (ROMA - Medicina Sperimentale e Patologia Sezione Virologia - La Sapienza), Marco Montano (ROMA - Virologia per Malattie Infettive Tor Vergata), Giovanni Cenderello (SAN REMO - Malattie Infettive), Angela Gonnelli (SIENA - Malattie Infettive), Maurizio Zazzi (SIENA Virologia), Michele Palumbo (TERNI - Malattie Infettive), Valeria Ghisetti (TORINO - Laboratorio di Virologia, Ospedale Amedeo di Savoia), Stefano Bonora (TORINO - Malattie Infettive Amedeo di Savoia), Palma Delle Foglie (TRENTO Malattie Infettive), Cristina Rossi (TREVISO - Malattie Infettive), Federica Poletti (VERBANIA - Malattie Infettive VERBANIA), Vincenzo Mondino (VERBANIA - Virologia), Marina Malena (VERONA - Centro di Medicina Preventiva-ULSS 20), Emanuela Lattuada (VERONA - Malattie Infettive). 


\section{References}

Bartlett JA, Buda JJ, von Scheele B, Mauskopf JA, Davis EA, Elston R, King MS, Lanier ER. 2006. Minimizing resistance consequences after virologic failure on initial combination therapy: a systematic overview. J Acquir Immune Defic Syndr 41:323-331.

Daar E, Tierney C, Fischl M, Collier A, Mollan K, Budhathoki C, Godfrey C, Jahed N, Katzenstein D, Sax P, and ACTG A5202 Study Team. ACTG 5202: Final Results of ABC/3TC or TDF/FTC with either EFV or ATV/r in Treatment-naive HIV-infected Patients. 17th Conference on Retroviruses and Opportunistic Infections (CROI), 16-19 Feb 2010, San Francisco (USA). Abstract 59LB.

DHHS Panel on Antiretroviral Guidelines for Adults and Adolescents. Guidelines for the Use of Antiretroviral Agents in HIV-1-Infected Adults and Adolescents. December 1, 2009. http://aidsinfo.nih.gov/contentfiles/AdultandAdolescentGL.pdf (last access on 13 Mar 2010).

Geretti AM. 2007. Epidemiology of antiretroviral drug resistance in drug-naïve persons. Curr Opin Infect Dis 20:22-32.

Gupta R, Hill A, Sawyer AW, Pillay D. 2008. Emergence of drug resistance in HIV type 1-infected patients after receipt of first-line highly active antiretroviral therapy: a systematic review of clinical trials. Clin Infect Dis 47:712-722.

Johnson VA, Brun-Vezinet F, Clotet B, Gunthard HF, Kuritzkes DR, Pillay D, Schapiro JM, Richman DD. 2009. Update of the drug resistance mutations in HIV-1: December 2009. Top HIV Med 17:138-145.

Lima VD, Gill VS, Yip B, Hogg RS, Montaner JS, Harrigan PR. 2008. Increased resilience to the development of drug resistance with modern boosted protease inhibitor-based highly active antiretroviral therapy. J Infect Dis 198:51-58.

Madruga JV, Berger D, McMurchie M, Suter F, Banhegyi D, Ruxrungtham K, Norris D, Lefebvre E, de Béthune MP, Tomaka F, De Pauw M, Vangeneugden T, Spinosa-Guzman S; TITAN study group. 2007. Efficacy and safety of darunavir-ritonavir compared with that of lopinavir-ritonavir at 48 weeks in treatment-experienced, HIV-infected patients in TITAN: a randomised controlled phase III trial. Lancet 370:49-58.

Mills AM, Nelson M, Jayaweera D, Ruxrungtham K, Cassetti I, Girard PM, Workman C, Dierynck I, Sekar V, Abeele CV, Lavreys L. 2009. Once-daily darunavir/ritonavir vs. lopinavir/ritonavir in treatment-naive, HIV-1-infected patients: 96-week analysis. AIDS 23:1679-1688.

Molina JM, Andrade-Villanueva J, Echevarria J, Chetchotisakd P, Corral J, David N, Moyle G, Mancini M, Percival L, Yang R, Thiry A, McGrath D; CASTLE Study Team. 2008. Once-daily atazanavir/ritonavir versus twice-daily lopinavir/ritonavir, each in combination with tenofovir and emtricitabine, for management of antiretroviral-naive HIV-1-infected patients: 48 week efficacy and safety results of the CASTLE study. Lancet 372:646-655.

Oldfield V, Plosker GL. 2006. Lopinavir/ritonavir: a review of its use in the management of HIV infection. Drugs 66:1275-1299. 


\section{1}

Ortiz R, Dejesus E, Khanlou H, Voronin E, van Lunzen J, Andrade-Villanueva J, Fourie J, De Meyer S, De Pauw M, Lefebvre E, Vangeneugden T, Spinosa-Guzman S. 2008. Efficacy and safety of oncedaily darunavir/ritonavir versus lopinavir/ritonavir in treatment-naive HIV-1-infected patients at week 48. AIDS 22:1389-1397.

Riddler SA, Haubrich R, DiRienzo AG, Peeples L, Powderly WG, Klingman KL, Garren KW, George T, Rooney JF, Brizz B, Lalloo UG, Murphy RL, Swindells S, Havlir D, Mellors JW; AIDS Clinical Trials Group Study A5142 Team. 2008. Class-sparing regimens for initial treatment of HIV-1 infection. N Engl J Med 358:2095-2106.

Soriano V, Köppe S, Mingrone H, Lutz T, Opravil M, Andrade-Villanueva J, Antunes F, Di Perri G, Podzamczer D, Taylor S, Horban A, Duiculescu D, de Rossi L. Prospective comparison of Nevirapine and Atazanavir/ritonavir both combined with Tenofovir DF/Emtricitabine in treatment-naive HIV-1 infected patients: ARTEN Study week 48 results 5th IAS Conference on HIV Pathogenesis, Treatment and Prevention (IAS 2009), July 19 -22, 2009, Poster LBPEB07.

Soulié C, Assoumou L, Ghosn J, Duvivier C, Peytavin G, Ait-Arkoub Z, Molina JM, Costagliola D, Katlama C, Calvez V, Marcelin AG. 2009. Nucleoside reverse transcriptase inhibitor-sparing regimen (nonnucleoside reverse transcriptase inhibitor + protease inhibitor) was more likely associated with resistance comparing to nonnucleoside reverse transcriptase inhibitor or protease inhibitor + nucleoside reverse transcriptase inhibitor in the randomized ANRS 121 trial. AIDS 23:1605-1608. 